University of Nebraska - Lincoln

DigitalCommons@University of Nebraska-Lincoln

Winter 1997

\title{
A Socioeconomic Portrait Of Prince Hall Masonry In Nebraska, 1900-1920
}

Dennis N. Mihelich

Creighton University, dennis@creighton.edu

Follow this and additional works at: https://digitalcommons.unl.edu/greatplainsquarterly

Part of the Other International and Area Studies Commons

Mihelich, Dennis N., "A Socioeconomic Portrait Of Prince Hall Masonry In Nebraska, 1900-1920" (1997).

Great Plains Quarterly. 1974.

https://digitalcommons.unl.edu/greatplainsquarterly/1974

This Article is brought to you for free and open access by the Great Plains Studies, Center for at DigitalCommons@University of Nebraska - Lincoln. It has been accepted for inclusion in Great Plains Quarterly by an authorized administrator of DigitalCommons@University of Nebraska - Lincoln. 


\title{
A SOCIOECONOMIC PORTRAIT OF PRINCE HALL MASONRY IN NEBRASKA, 1900-1920
}

\author{
DENNIS N. MIHELICH
}

$\mathrm{O}$ Freemasons initiated Prince Hall (his name, not a title) and fourteen other African Americans after the white colonial lodge at Boston had rejected their petition. Independence did not alter the attitude of white American Masons; thus, a separate black Masons' organization evolved. Hall secured a charter from the "mother" grand lodge in England and reconstituted his group as the African Grand Lodge of North America. Following his death in 1807 the fraternal order renamed itself in his honor.

Dennis N. Mihelich is associate professor of history at Creighton University and the author of several articles on the Urban League and on Prince Hall Masons.

[GPQ 17 (Winter 1997): 35-47]
Prior to the abolition of slavery Prince Hall Masonry spread slowly among the free black population in the northern and border states. The fraternity established a confederation structure in which each state could create a sovereign grand lodge. After the Civil War membership mushroomed and migrating African Americans carried the institution to the trans-Missouri West. Prince Hall Masons affiliated with the Missouri Grand Lodge organized the first blue (subordinate) lodge in Nebraska at Omaha in 1875. By the end of the century blue lodges also existed in Lincoln, Hastings, Grand Island, Alliance, and Scottsbluff. The Great Migration of World War I increased the membership significantly, making it feasible for four Omaha lodges to join with those in the other five towns to form the independent Prince Hall Mason Grand Lodge of Nebraska in 1919.

Existing scholarship argues that Masonry among blacks was a middle-class phenomenon that produced class strife in the African American community. Until recently in the post civil rights era, the delineation of classes within the segregated black caste in the United States has produced conflicting hierarchical schemes and 
controversy. Nonetheless, the titles of William A. Muraskin's Middle-class Blacks in a White Society: Prince Hall Freemasonry in America and Loretta J. Williams's Black Freemasonry and Middle-Class Realities announce their socioeconomic interpretations. ${ }^{1}$ The charter members of the Prince Hall Grand Lodge of Nebraska, however, exhibited a wide range of wealth, incomes, and occupations. The $\mathrm{Ne}$ braska story demonstrates the impact and the persistence of regional diversity in American history in general and in African-American history in particular. The desire for a sovereign grand lodge and the relatively small African-American population precluded elitist class-based exclusion. Prince Hall Masonry in Nebraska was not the overwhelmingly middleclass institution described by previous scholars; it was a multi-class fraternity consisting of individuals who accepted a Christian code of values (allegorically cast in reference to the craft of stone masons), who demanded moral and ethical conduct, and who promoted "selfhelp" and "racial uplift" for the entire black community.

An analysis of the few rosters in the Nebraska materials for the pre-Grand Lodge years supports the multi-class interpretation and highlights the nineteenth-century origins of the characteristic. For the pre-World War I years, however, anecdotal evidence, such as stories in the black press, suggested that Prince Hall Masonry in Nebraska at the turn to the twentieth century took on an elitist aura. Obviously, news coverage stressed the entertainments of the "leading lights" of the community, meaning its professionals, politicians, and entrepreneurs.

In comparison, the rosters reveal the wide variety of unskilled, skilled, and service-area jobs held by the majority of Prince Hall Masons. They also reveal how specific jobs changed labor categories as the Nebraska economy evolved and the Great Migration altered the circumstances of the black community. For example, barbering for a white clientele offered some blacks an opportunity at skilled service or entrepreneurship that largely disappeared after World War I. On the other hand, unskilled and semi-skilled industrial employment in the rapidly expanding meat-packing companies mushroomed during and after the First World War.

\section{PRINCE Hall MASONS BEFORE 1900}

The oldest roster in the Nebraska files lists the membership of only one Omaha lodge, Rescue \#25 (Iowa Jurisdiction) in 1899. It portrays a multi-class group, although the end-ofthe-century date means it cannot necessarily be read backward to an earlier era. The occupations of 17 of 23 members who could be traced included 4 barbers, 4 porters, 3 retired, 2 laborers, a postal clerk, a fireman, a waiter, and a janitor. ${ }^{2}$ These were among the survivors of the depressed 1890s that had witnessed the diminution of the black population of Omaha from 4566 in 1890 to 3443 in 1900.

Perchance the earliest lodges during the 1870 s and 1880 s differed in occupational composition. The depression of the 1890 s may have drastically altered the economic opportunities for blacks in Nebraska, thus affecting the membership in Prince Hall Masonry. Perhaps a dwindling number of persons in middle-class occupations were forced to accept stable bluecollar workers in order to maintain the viability of the lodge. Alternatively, Prince Hall Masonry may have followed the route of the United Order of True Reformers, which began as a middle-class dominated benevolent society but rapidly evolved into a multi-class organization. ${ }^{3}$ Moreover, as Roger Lane has pointed out, the 1880 s had witnessed a notable upsurge in the education of black professionals; thus, they may have played a more prominent role in Prince Hall Masonry in $\mathrm{Ne}$ braska prior to the depression of $1893 .{ }^{4}$ On the other hand, the depressed nineties had sounded the death knell for Marvin Lodge \#127 (Missouri Jurisdiction) located at Hastings, Nebraska, and most of the adult African Americans living in that community had worked as domestic servants. ${ }^{5}$ Moreover, Rescue Lodge rosters mirror the situation found in 
the black communities of Cleveland, Detroit, and the cities of the Pacific Northwest. ${ }^{6}$ Therefore, it is likely that the multi-class nature of Prince Hall Masonry in Nebraska dated from its origins in the state and that the membership of Rescue Lodge in 1899 reflected an established tradition of occupational diversity.

\section{EARLY TWENTIETH CENTURY}

At any rate, the early twentieth-century rosters document the occupationally diverse, multi-class nature of Prince Hall Masonry in Nebraska. At the turn to the twentieth century it included the professional and entrepreneurial elite as well as the skilled service and industrial middle class, and the unskilled laborer. To lump these distinct groups into one category or to generalize the membership as middle-class based on the officer corps or a percentage of the membership camouflages the manner in which Prince Hall Masonry, at least in Nebraska, bridged the class lines of the compressed social scale that existed in the black communities. Because the application of white middle-class wealth, income, and occupational standards result in a lower-class placement for almost all blacks during the late nineteenth and early twentieth centuries, several scholars have introduced non-economic traits such as education, personal values, and social behavior to categorize class among African Americans. Important as these characteristics are to understanding the divisions within black society, they are virtually impossible to apply. Such information is not available for the hundreds of charter members of the Prince Hall Mason Grand Lodge of Nebraska. Moreover, to imply that a Prince Hall Mason had the "correct" values and thus was middle class is a tautology that relies on stereotypes and denigrates unskilled and semi-skilled workers. Class and values interact but are not the same. Belief in hard work, thrift, temperance, etc., is neither exclusive to the middle class nor held by all middle class individuals. Class models based on qualitative characteristics that cannot be measured using sources such as census data are not useful in my study. I am, therefore, arguing that a substantial class difference existed between a physician, an electrician, and a porter in a pool hall, even though they socialized together and although they may have held the same values. ${ }^{\text {? }}$

By 1908, Rescue's membership had jumped to 39 , revealing renewed African-American migration to the area prior to World War I and the Great Migration. Between 1900 and 1910 the black population in Nebraska increased by 1420 ( 22 percent) to a total of 7689 . Omaha absorbed 983 of the total, average for a midwestern or western city prior to the Great Migration. Only seven cities outside the old Confederacy had a black population of 10,000 or more in 1910. Thus, while Omaha's black community was much smaller than Chicago's, it was comparable to communities in Cleveland, Minneapolis, Denver, and Los Angeles. ${ }^{8}$

During the first decade of the twentieth century 20 individuals joined Rescue lodge; the occupations for 8 of them could be identified: 3 laborers ( 2 of them worked for a meat-packing firm, possibly survivors from the black strikebreakers used in $1904^{\circ}$ ), 2 janitors, 2 entrepreneurs, and a porter. Finally, as of 1913, 22 more men were initiated, although total membership only climbed to 41 . The high proportion of initiates to total membership demonstrates, on the one hand, the mobility of transient opportunistic men searching for success and, on the other hand, the economic insecurity that led to frequent suspension of members for non-payment of dues-although some individuals probably ceased payment and were suspended because they no longer wanted to be members.

The final 22 initiates maintain the variety of occupations of the 13 fraters who could be identified, there were 8 waiters, 3 porters (2 Pullman porters, the first time anyone made that specific designation), a fireman at a meatpacking house, and the city inspector of weights and measures, for decades a black patronage position. ${ }^{10}$ Rescue Lodge illustrated the variety of vocations, from professional to unskilled, at which black Masons labored and 
demonstrated the significance of service-sector employment, including the pervasive category of porter. The 1920 census, which not only asked for a person's job but also the nature of his or her employer, revealed that men listing themselves as porters worked at a wide array of establishments, including barber shops, saloons, retail stores, banks, railroad stations, clubs, restaurants, and pool halls.

The only pre-Great Migration Nebraska roster from the Missouri Jurisdiction discloses the same occupational composition for eastern Nebraska, except that two of the smalltown lodges included farmers. In Omaha in 1912, Rough Ashler had 56 members (29 identified) and Excelsior had 27 members (19 identified). Within that group were 2 professionals, 3 skilled laborers, 6 entrepreneurs, 8 unskilled workers, and 29 service-area employees. Lebanon lodge in Lincoln had 69 members (47 identified) including one physician, 2 entrepreneurs, 13 unskilled laborers, and 26 service-area workers. Two members were retired and one listed himself as a student.

In comparison, the central and western $\mathrm{Ne}$ braska lodges of the Missouri jurisdiction demonstrated a slightly different occupational configuration. In 1912 St. John's in Grand Island had 15 members and Shelton \#87 in Alliance had 19 members, but only 7 and 5 members, respectively, could be identified, even after line-by-line scrolling the 1910 census for the entire county of each lodge. Possibly members in these less populated areas of Nebraska lived in other counties or had migrated within the two-year interval between the census and the roster, but the low identification rate may indicate that the alleged under counting of blacks by the census bureau is neither recent nor solely urban. With few exceptions, black professionals and entrepreneurs did not reside in western or central Nebraska; the small African-American populations could not support lawyers, physicians, or dentists, and even the clergy were itinerants. George A. Flippin, M.D., of Stromsburg was a rare exception, as were extraordinary entrepreneurs sup- ported by the white community, such as J.S. Craig of Hastings and Sam Shelton of Alliance. Most of the Masons in central and western $\mathrm{Ne}$ braska lodges found unskilled and service-area jobs, many associated with the railroad or allied establishments such as hotels. ${ }^{11}$

\section{THE GRAND LODGE OF NEBRASKA}

The rosters of the charter members of the Grand Lodge of Nebraska show that Prince Hall Masonry retained its multi-class character after the Great Migration, which both increased the membership of extant lodges and sparked the formation of new ones. Of the 513 men, however, 137 ( 27 percent of the membership) could not be identified in the 1920 census or in the city directories. Most city directories in Nebraska ceased using the (c) to designate "colored" in 1918, although M-H Directory Service of Brush, Colorado not only applied the (c) but also an (m) for Mexican in its 1939 publication for Alliance. This odious identification was functional for researchers so it is significantly more difficult to trace individuals during the years of rapid expansion immediately prior to the creation of the Nebraska Grand Lodge than for earlier years.

Unfortunately, Masonic record keeping exacerbated the problem. The rosters contain frequent misspellings (obvious references to the same person spelled differently), or give the last name only, or initial(s) plus last name. The absence of addresses, except on occasion for officers, eliminates the most obvious way to distinguish among people with common names-e.g., the 1920 Omaha City Directory listed nine men named Robert Johnson; the census revealed that three of them were black; which one was the Prince Hall Mason?

The census presented several problems. The soundex, a finder system that converts names to numbers in order to minimize spelling errors or problems with homophonous names, keys on heads of households, making it difficult to track lodgers. Many blacks simply did not get listed on the soundex. I found scores of unrecorded Prince Hall Masons in the manuscript 
census by scanning heavily black populated enumeration districts line by line.

Many factors contributed to the 1920 census undercount. Enumerators were poorly paid and often incompetent, and they were instructed to obtain information about families not at home from just about anyone living nearby. Many people avoided being counted because they feared data would go to the recently created Internal Revenue Service or Selective Service boards. ${ }^{12}$ The Red Scare with its Palmer Raids restrained immigrant and African American participation. Omaha's last lynching, followed by a race riot, had preceded the count by only three months and probably intimidated both the white enumerators and the black residents. Thus, Rough Ashler \#1 had 129 members listed on its charter roster; 45 could not be found on the census rolls, yet 16 of those 45 had listed themselves in the City Directory of 1918 , the last with the (c) designation. A total of 55 charter members from the rosters of 8 different lodges not listed in the 1920 census ( $10 \%$ of the membership), were found in city directories. These men were not transients, although many of the others probably had come to Omaha during the Great Migration, may have been single, and had not established themselves as a head of a household. The absence of men in the city directory from the census is evidence of the under counting of African Americans.

\section{Housing PatTerns of Prince Hall MASONS}

The 1920 census asked for information related to family, residence, personal characteristics, education, nativity, and occupation (Table 1). By 1920 Prince Hall Masons were becoming ghettoized in Omaha. Twenty years earlier only 7 of the 17 identified members of Rescue Lodge lived in the area that became the Near Northside, one of the eventual de facto segregated residential areas for blacks in Omaha. (A second one developed adjacent to the stockyard-meatpacking area in the former suburb of South Omaha, annexed in 1915.)
Thirteen of the 16 identified new initiates from 1913 resided on the Near Northside. Despite their "respectability" and relative economic security, Prince Hall Masons did not escape the trend in housing discrimination. While blacks found themselves increasingly confined, these areas actually remained significantly integrated until after the second Great Migration of World War II because of the relatively small number of African Americans in the total population. ${ }^{13}$

Researching mobility in pre-World War I Omaha, Howard Chudacoff traced the residential patterns of a "few" blacks during the 1890s who "occupied the lower occupational strata" and found that they "moved in directions and frequencies similar to those of their white counterparts." By 1902, however, housing notices "for colored families" began to appear in the local press, and "the segregation index for blacks increased from 36.2 in 1910 to 47.9 in $1920 . " 14$ The absence of nineteenthcentury rosters for the other lodges precludes longitudinal analysis of residential configurations in the other Nebraska cities.

The Great Migration solidified the segregated pattern in Omaha. Of the 249 (of 349) identifiable Prince Hall Mason heads of household residing in the city in 1920,83 percent lived in the areas subsequently described as the ghettos. Only four of the sixteen Prince Hall householders in the formerly independent area of South Omaha resided beyond the stockyards vicinity and a mere 40 of 233 heads of households in historic Omaha lived outside the Near Northside. Fourteen non-ghetto residents were identified in the City Directory, which did not distinguish between a homeowner and a renter, but 18 of the 42 identified owned their residences, while one was a medical student in a dormitory, 2 lived in an all-black hotel operated for Union $\mathrm{Pa}$ cific Rail Road employees in an otherwise allwhite neighborhood, and another 5 were live-in janitors at white-occupied apartment buildings. In some cases employment, not equal access, determined a person's non-ghetto residence.' The two most significant areas of 
TABLE 1

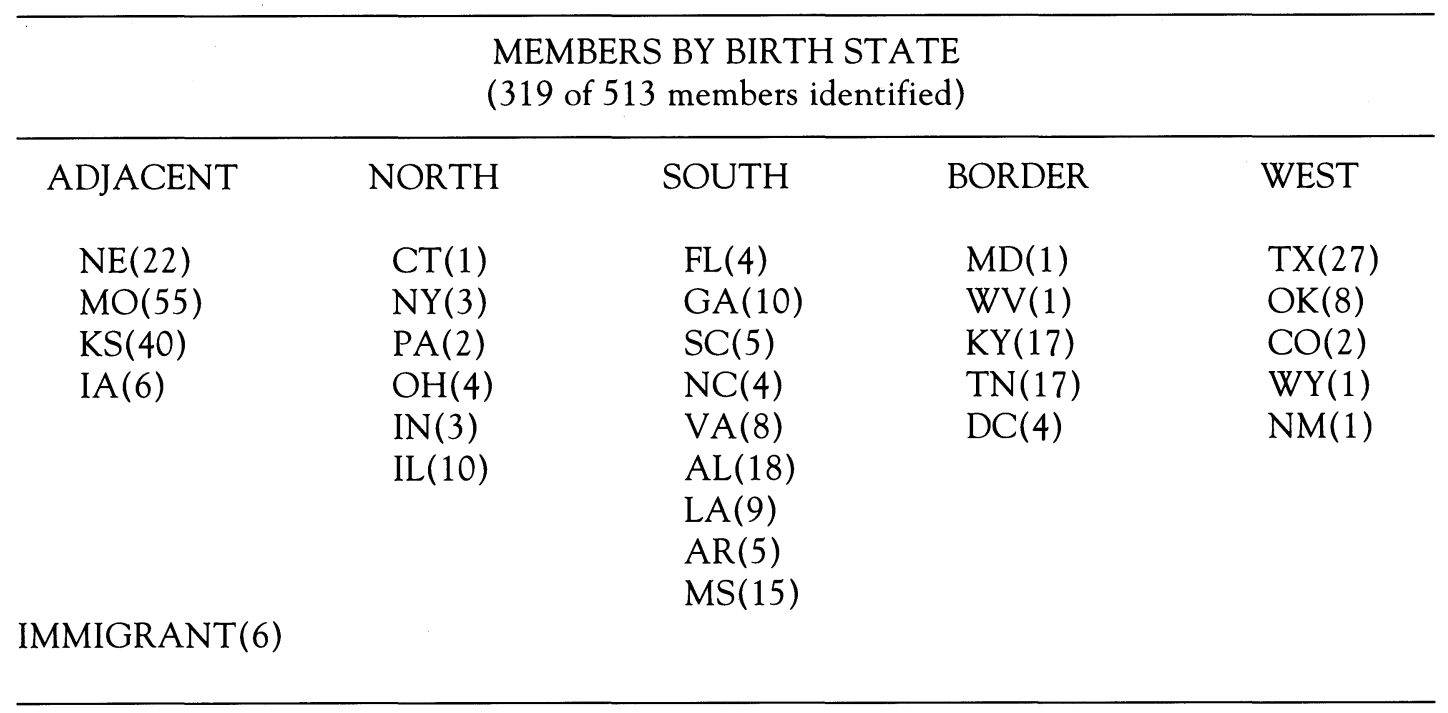

MEMBERS BY MARITAL STATUS AND FAMILY STATUS

(318 members identified)

(253 married members identified)

$$
\begin{aligned}
& \text { divorced }(5) \\
& \text { widowed( } 8) \\
& \text { single(52) } \\
& \text { married }(253)
\end{aligned}
$$

$$
\begin{aligned}
& 0 \text { children(141) } \\
& 1 \text { child }(48) \\
& 2 \text { children( } 25) \\
& 3 \text { children(18) } \\
& 4 \text { children(10) } \\
& 5 \text { children(0) } \\
& 6 \text { children(1) }
\end{aligned}
$$

\section{MEMBERS BY RACE}

(318 identified)

white(2)

mulatto(105)

$\operatorname{black}(211)$
MEMBERS BY AGE

(318 identified)

$$
\begin{aligned}
& 21-30 \text { years }(70) \\
& 31-40 \text { years }(95) \\
& 41-50 \text { years }(92) \\
& 51-60 \text { years }(43) \\
& 61-70 \text { years }(11) \\
& 71+\text { years }(7)
\end{aligned}
$$

MEMBERS BY RESIDENCE

(306 identified)

owner-freeholder(43)

owner-mortgage holder(85)

renter(111)

lodger(67) 
non-ghetto residence for Prince Hall Masons consisted of a smattering of homeowners on contiguous streets north and west of the contemporary Near Northside and a group of owners and renters in an area stretching a few blocks south of Dodge Street from 11th to 30th.

Despite the increased concentration, or possibly because ghettoization enabled African Americans to purchase dwellings in older neighborhoods with depressed values, Prince Hall Masons displayed a high percentage of home ownership. Of 306 Masons identified by type of residence, 128 or 42 percent owned their home ( 43 freeholders and 85 with a mortgage). The 207 missing cases probably distort the rate of home ownership upward, as property owners were most likely to list themselves in a city directory or to get counted in a census. Yet, even assuming that all 207 were nonhomeowners, possibly distorting in the opposite direction, the homeowners represented 25 percent of the 513 total Prince Hall Masons, a figure still above the national average for black home ownership in 1920 (22.3 percent)..$^{15}$

Obviously, the rate of home ownership increased with age. Lodgers were predominantly young, while renters spread about evenly across the age spectrum. Well over 90 percent of the homeowners were married, although one half of the married Prince Hall Mason couples rented their living space. Less evident was the geographic dispersal of home ownership: 58 percent of the lodge members in Grand Island, 49 percent in Lincoln, and 43 percent in Omaha owned their homes, while fewer than a quarter of the Prince Hall Masons in Alliance, Hastings, and Scottsbluff did so. The three smaller towns had only a few black residents, mostly associated with the railroad. Short stays and lack of available housing may also have influenced the ownership rates.

Generally occupation level did not determine home ownership. A similar percentage of unskilled laborers (39 of 114,34 percent) owned a home as did professionals ( 6 of 17, 35 percent). The percentage of unskilled laborers who purchased homes matched the percentage for the entire Grand Lodge of Nebraska and speaks well for the usually ignored social mobility of that class. Scholars have documented property acquisition among blue-collar European migrants, but not among African Americans. Home ownership figures for the Prince Hall Masons of Nebraska compare favorably with those of immigrants in Northern cities. ${ }^{16}$ Prince Hall Masons employed in the service sector acquired property at a slightly higher rate ( 41 of 98,42 percent), while 62 percent of entrepreneurs (19 of 29) were homeowners.

\section{SKIN COLOR AND ClASS ISSUES}

Skin tone also frequently denotes class division among African Americans. According to William Muraskin, Prince Hall Masonry's "selectivity and elite character in the nineteenth century" gave it "a strong 'mulatto' caste." He claimed that "intraracial 'blackballing' by light-skinned blacks against darker ones was probably fairly widespread in the Order," and continued "well into the twentieth century. The relative 'democratization' of the fraternity, by the admission of middle-class, non-elite, darker blacks appears to have come after the turn of the century when thousands of new members entered." Muraskin admitted that "hard evidence for the color factors in black Masonry are hard to come by," but he cited photographs of Masonic leaders and an interview with a "prominent California Mason."17 Historical and geographic factors, however, may have been more significant than intraracial color prejudice. As of 1850, "the proportion of mulattoes [sic] in the free colored population greatly exceeded the proportion in the slave population," and a man had to be free to join Prince Hall Masonry. Furthermore, during the second half of the nineteenth century the West contained the highest percentage of mulattoes within its black population. ${ }^{18}$ The evidence from Nebraska, at any rate, does not support a powerfully selective racial bias.

The few extant photographs of nineteenthcentury Prince Hall Masons in Nebraska do not necessarily show mulatto predominance 
and their evidence, like that of contemporary newspapers, distorts the image. Using the handful of leaders to characterize the entire order is problematic. Local circumstances probably produced a wide variety of demographics. For example, an 1897 photograph of Prince Hall Masons from Mississippi and another turn-ofthe-century picture of a military lodge that had recently served at Ft. Robinson, Nebraska, reveal a rich diversity of skin tones with no apparent numerical or "political" superiority by light-skinned individuals. ${ }^{19}$ Mulattos certainly played a significant role but, in the numerically small black communities in Nebraska, they could not establish a light-skinned restriction. Moreover, dark-skinned, Negro-featured individuals such as M. O. Ricketts, a physician, a Nebraska state legislator during the 1890s, worshipful master in Omaha, and subsequent Grand Master of the Missouri jurisdiction, demonstrated that non-mulattos not only gained entrance but rose to the very top of the fraternity and the community.

The 1920 census revealed that 33 percent of the 318 identified Prince Hall Masons claimed mulatto as their "race or color." Ultimate racial designation, however, relied upon "the personal impression of the enumerator. . . . The delineation between black and mulatto [the two choices specified, Negro was not used] was also at the discretion of the enumerator; black being defined as 'Negroes of full blood' and mulatto as 'all Negroes having some portion of white blood." "20 The Census Bureau's loose definition renders its figure suspect for calculating the actual size of a light-skinned elite. Nonetheless, Prince Hall Masons took pride in the mulatto classification in 1920. In all eleven cases where a black person had married a mulatto and the couple listed children, they designated their offspring as mulatto (and the enumerator agreed). How many of the adult mulattos also fit that imprecise definition? Only two interracial marriages existed in the fraternity; both were black men with white wives, despite the state anti-miscegenation law. As the census did not list the location of marriages or the length of residence in a state, one can- not ascertain when or where those unions commenced or what they mean in terms of the $\mathrm{Ne}$ braska miscegenation statute.

Although the enforcement of the bans on interracial marriages probably differed according to place and time, the rapid spread of bans during the post-Civil War era indicated widespread official opposition to such marriages, and miscegenation was "extremely uncommon" (less than .2 percent) in the United States before World War II. ${ }^{21}$ A sizeable percentage of Prince Hall Masons of all ages, but particularly those between 31 and 60 years old, designated themselves as mulatto. It is not possible, however, to calculate the actual number of mulattos as opposed to those who were only a quarter or an eighth or less in descent from one race or the other. While it is probable that blacks in Nebraska manifested some sort of the widely reported color status system, none of the evidence suggests that a restrictive light-skinned elite dominated Prince Hall Masonry.

\section{OCCupational Status of PRINCE HALl MASONS}

Neither did an economic elite dominate the fraternity in Nebraska. Prince Hall Masons worked at an array of specific jobs that reflected the general distribution of blacks in the Omaha and Nebraska economies (Tables 2 \& 3). The fraternity presented a cross section of the employed African American community, not a distorted elite segment. More than one-third of the members held unskilled jobs while another 32 percent worked in the service sector. Service sector jobs on the railroads were more prestigious and paid better than those in small local establishments. Only 26.9 percent of the members occupied the traditional middle class and elite occupations such as skilled laborer, white collar worker, civil servant, professional, or entrepreneur, but railroad cooks, porters, and so on claimed middle class status. Prince Hall Masonry in Nebraska united all respectable classes in the black population that could afford and that desired membership. Surprisingly, although 
TABLE 2

OCCUPATIONS

(364 of 513 members identified)

\begin{tabular}{|c|c|c|}
\hline SERVICE & UNSKILLED & SKILLED \\
\hline $\begin{array}{l}\text { pullman porter(10) } \\
\text { redcap }(1) \\
\text { RR porter(15) } \\
\text { RR waiter( } 7) \\
\text { RR cook(6) } \\
\text { porter(25) } \\
\text { cook }(12) \\
\text { waiter }(24) \\
\text { driver(4) } \\
\text { trucker(6) } \\
\text { caterer(1) } \\
\text { barber(4) } \\
\text { watchman(3) }\end{array}$ & $\begin{array}{l}\mathrm{RR} \text { laborer(16) } \\
\mathrm{RR} \text { janitor(2) } \\
\text { janitor(38) } \\
\text { caretaker(1) } \\
\text { farm laborer(2) } \\
\text { laundry worker( } 7) \\
\text { laborer, common }(50) \\
\text { packinghouse labor(25) } \\
\text { government labor }(1)\end{array}$ & $\begin{array}{l}\text { blacksmith(1) } \\
\text { painter(3) } \\
\text { packinghouse, skilled (8) } \\
\text { fireman at a business (2) } \\
\text { shoemaker(1) } \\
\text { auto mechanic(5) } \\
\text { machine mech(1) } \\
\text { electrician(1) } \\
\text { mason(4) } \\
\text { plasterer(3) } \\
\text { tailor }(1)\end{array}$ \\
\hline WHITE COLLAR & GOVERNMENT & PROFESSION \\
\hline $\begin{array}{l}\text { clerk(4) } \\
\text { messenger(2) } \\
\text { headwaiter(1) } \\
\text { steward(2) } \\
\text { manager(1) } \\
\text { musician(7) }\end{array}$ & $\begin{array}{l}\text { clerk(1) } \\
\text { policeman(4) } \\
\text { fireman(5) }\end{array}$ & $\begin{array}{l}\text { physician(3) } \\
\text { lawyer(1) } \\
\text { engineer(2) } \\
\text { medical student }(1) \\
\text { clergy(3) } \\
\text { dentist(1) }\end{array}$ \\
\hline
\end{tabular}

\section{ENTREPRENEUR}

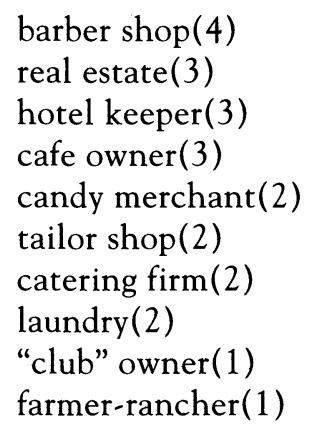

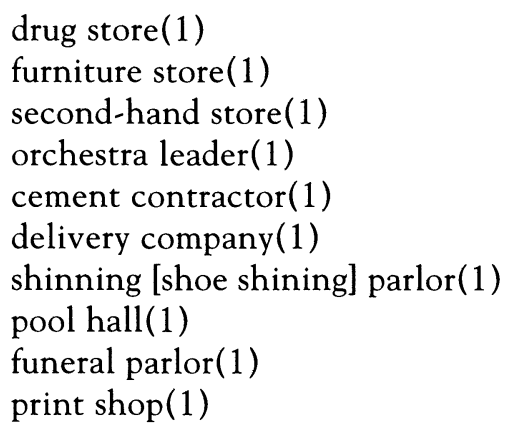

unemployed(10)

Note the absence of teachers. Neither the state nor the municipalities established separate segregated school systems, but uniformly the school districts refused to hire African American teachers until the World War II era. 
TABLE 3

"COLORED LABORERS IN OMAHA"

MONITOR, 12 May 1922

stenographer
hairdresser
seamstress
dressmaker
milliner
stationary engineer
electricians
trained nurse
clerks \& carriers
carpenter
painter
paper hanger
brick \& stone mason
auto mechanic
paving bricklayer
asphalt finisher
butcher
trimmer

$\begin{array}{lr}\text { barber } & 35 \\ \text { masseur } & 4 \\ \text { sign painter } & 1 \\ \text { iron molder } & 2 \\ \text { chauffeur } & 50 \\ \text { manicurist } & 15 \\ \text { porter-waiter-cook @ hotel or RR } & 380 \\ \text { paving worker } & 100 \\ \text { RR shop worker } & 150 \\ \text { smelter } & 200 \\ \text { factory worker } & 100 \\ \text { RR grading labor } & 200 \\ \text { packing house worker } & 2500 \\ \text { miscellaneous } & 1000 \\ \text { dairyman } & 1 \\ \text { plumber } & 3 \\ \text { grading \& RR contracting } & 1\end{array}$

The lead article claimed to analyze 5469 jobs but the list contains only 4964. Curiously, it lists no domestics, porters-waiters-cooks outside of hotels and the RR, and no common laborers, unless they fit its "miscellaneous" category. The 1920 census certainly had numerous individuals listing themselves in those categories."

three-fourths of the members toiled at nonmiddle-class jobs, only one-fourth (65 of 254) of the wives of Prince Hall Masons worked. The percentage of wage-earning wives shrinks further when one considers that five wives assisted their husbands in family businesses and another eleven provided services from their homes. The proportion of Prince Hall Mason working wives was almost half the average for blacks in Northern cities with limited industrial employment for black males. ${ }^{22}$ Moreover, despite the oft repeated claim that entrepreneurs joined fraternities to establish business contacts, the Prince Hall Masons of Nebraska attracted only a few of the limited number of black entrepreneurs in the state. Increasing segregation and discrimination pro- vided opportunity to blacks elsewhere, but the black population in Nebraska cities was too small to support black-owned businesses serving black-only clienteles.

\section{A Multi-Class Fraternity}

While I differ from him on job categorization and socio-economic interpretation, Muraskin's occupational list for Good Hope Lodge of Oakland, California, for 1923 reads very much like my Nebraska statistics (Table 4). I did not separate "public employees" and "railroad men" as categories, classifying jobs by socio-economic and skill levels (i.e., a janitor at a post office and a laborer at a railroad yard are unskilled). Both our lists reveal 


\section{TABLE 4}

\section{OCCUPATIONS OF GOOD HOPE PRINCE HALL MASONIC LODGE, OAKLAND, CALIFORNIA}

The year 1923 presents the first detailed information on the membership of Good Hope Lodge itself. In that year the lodge had ninety-three members, of whom seventy-three were identifiable in the city directory, presenting the following breakdown:

\begin{tabular}{lcl}
\hline CATEGORY & NUMBER & \multicolumn{1}{c}{ DESCRIPTION } \\
Businessmen & 9 & $\begin{array}{l}3 \text { restauranteurs, } 2 \text { realtors, } \\
1 \text { barber, } 1 \text { bootblack (business), } \\
1 \text { undertaker, } 1 \text { gardener (business) }\end{array}$ \\
Skilled Labor & 7 & $\begin{array}{l}2 \text { carpenters, } 3 \text { plasterers, } 1 \text { tailor, } \\
1 \text { machinist }\end{array}$ \\
White Collar & 3 & 2 clerks, 1 insurance agent \\
Public Employees & 7 & $\begin{array}{l}1 \text { post office, } 2 \text { firemen, } \\
2 \text { city janitors, } 1 \text { library guard, } \\
1 \text { city street laborer }\end{array}$ \\
Railroad men* & & $\begin{array}{l}12 \text { waiters, } 5 \text { cooks, } 1 \text { car cleaner, } \\
13 \text { porters }\end{array}$ \\
Unskilled Labor & 31 & $\begin{array}{l}8 \text { laborers (unspecified), } \\
4 \text { stevedores, } 2 \text { janitors, } \\
1 \text { chauffeur }\end{array}$ \\
& 15 & 1 trainer \\
\hline
\end{tabular}

*We know that all of the porters worked for the railroads since there were no black porters in Oakland stores at the time (interview with Royal Towns, May 1968). We cannot be sure that all of the waiters or cooks worked for the railroad; some probably did not, though most probably did. Source: William A. Muraskin, Middle-class Blacks in a White Society: Prince Hall Freemasonry in America (Berkeley: University of California Press, 1975), p. 93.

a significantly high percentage of unskilled workers fraternizing with professionals. ${ }^{23}$ Those multi-class bodies contrast sharply with the white Masons of Oakland. Lynn Dumenil constructed an employment chart for three white Mason lodges in 1919. The figures revealed few blue-collar workers of any type. Less than
1 percent of the membership of each lodge was unskilled labor and only one of the three lodges nudged above 6 percent of its members in the semi-skilled category. ${ }^{24}$ In comparison to the distinctly middle-class white Masons of Oakland, the Prince Hall Masons of Nebraska were multi-class. 
Each of the various Nebraska lodges included members from the full range of occupational categories. While at least 30 percent of the members of each lodge worked as unskilled laborers, for geographic-economic reasons the three western Nebraska lodges had significantly higher rates-Alliance No. 7, 43.8 percent; True American No. 6 in Grand Island, 58.8 percent; and Marvin No. 5 in Hastings, 61 percent. None of the lodges had an elite membership based on class distinctions. All were multi-class groups of neighbors and co-workers. The differences among lodges were based on location and history, but the social and economic variations were minor and the non-elite pattern held for the grand lodge as a whole. Because of Nebraska's small membership pool and restricted economic opportunities, the Prince Hall Grand Lodge of Nebraska was a multi-class fraternity, an exemplary American institution of young geographic and socially (within the constricted scale of the segregated community) mobile African Americans.

\section{NOTES}

I would like to thank Lynn Dumenil, David Fahey, and Charles L. Harper for commenting on drafts of this article.

1. William A. Muraskin, Middle-class Blacks in a White Society: Prince Hall Freemasonry in America (Berkeley: University of California Press, 1975); Loretta J. Williams, Black Freemasonry and MiddleClass Realities (Columbia: University of Missouri Press, 1980).

2. Roster in the Proceedings of the Twelfth Annual Communication, Prince Hall Grand Lodge of Iowa, 1899, pp. 42-43. Author's possession. Individual's occupations were derived from Omaha City Directory, 1899.

3. James D. Watkinson, "William Washington Browne and the True Reformers of Richmond, Virginia," The Virginia Magazine of History and Biography 97 (July 1989): 379-80.

4. Roger Lane, "Black Philadelphia Then and Now: The 'Underclass' of the Late 20th Century Compared with Poorer African-Americans of the Late 19th Century," in Drugs, Crime, and Social Isolation: Barriers to Urban Opportunity, ed. Adele V. Harrell and George E. Peterson (Washington, D.C.: The Urban Institute Press, 1992), pp. 30-31.
5. Dorothy Weyer Creigh, Adams County: The Story (Hastings, Nebraska: Adams County-Hastings Centennial Commission, 1972) pp. 330-31.

6. All of the following indicated that Prince Hall Masonry in their locale was a multi-class institution: Kenneth Kusmer, A Ghetto Takes Shape: Black Cleveland, 1870-1930 (Urbana: University of Illinois Press, 1976), p. 97; David M. Katzman, Before the Ghetto: Black Detroit in the Nineteenth Century (Urbana: University of Illinois Press, 1973), p. 148; and Quintard Taylor, "The Emergence of Black Communities in the Pacific Northwest: 1865 1910," Journal of Negro History 64 (1979): 343-44. Kusmer and Katzman analyzed Prince Hall Masonry directly, while I derive Prince Hall masonry membership in the Pacific Northwest from Taylor's discussion of employment patterns of the small black population in the area.

7. For analysis of the African American class structure prior to World War II see W. E. B. DuBois, The Philadelphia Negro (1899; rpt. New York: Benjamin Bloom, 1967); St. Clair Drake and Horace Cayton, Black Metropolis, rev. ed. (New York: Harper and Row, 1962); and Gunnar Myrdal, An American Dilemma (1944; rpt. New York: McGraw-Hill, 1964).

8. Bureau of the Census, Negro Population, 1790 1915 (Washington, D.C.: Government Printing Office, 1918), pp. 92-93, 100.

9. William C. Pratt, "Divided Workers, Divided Communities: The 1921-22 Packinghouse Strike in Omaha and Nebraska City," Labor's Heritage 5 (Winter 1994): 56.

10. Proceedings of the annual communications of the Prince Hall Grand Lodge of Iowa for 1900 . 1913. Author's possession. Occupations from Omaha City Directory, 1900-1913 and from Manuscript Census of the United States, 1900 and 1910.

11. Rosters in the Proceedings of the Forty-sixth Annual Communication, Prince Hall Grand Lodge of Missouri, 1912, pp. 117-35. Author's possession. Occupations from Alliance City Directory, 1939; Grand Island City Directory, 1912; Hastings City Directory, 1912; Lincoln City Directory, 1912; Omaha City Directory, 1912; and Manuscript Census of the United States, 1910 and 1920.

12. Kellee Green, "The Fourteenth Numbering of the People: The 1920 Federal Census," Prologue 23 (Summer 1991): 133-35.

13. The boundaries for the Near Northside are described in Dennis N. Mihelich, "World War II and the Transformation of the Omaha Urban League," Nebraska History 60 (Fall 1979): 402, 405; I culled the information from John P. Zipay, "The Changing Population of the Omaha SMSA, 1860. 1967" (Omaha Urban Research Project, University of Omaha, 1967), pp. 11-15; James R. Mead, "An 
Ecological Study of the Second Ward of Omaha" (master's thesis, University of Omaha, 1953), pp. 10-34; Murphy Cleophus Williams, "An Ecological Study of the Negro in Ward Seven" (master's thesis, University of Omaha, 1947), pp. 6-7.

14. Howard Chudacoff, Mobile Americans: Residential and Social Mobility in Omaha, 1880-1920 (New York: Oxford University Press, 1972), pp. 127, 155.

15. Each characteristic in the analysis of the economic attributes of the Prince Hall Masons is based on available data. The absolute number in each group analyzed varies because census enumerators on occasion failed to record information for a question or because an individual was identified through a city directory that provided limited information on residence and occupation. Bureau of the Census, Negroes in the United States, 192032 (Washington D.C.: Government Printing Office, 1935), p. 260.

16. Stanley Lieberson, Ethnic Patterns in American Cities (Glencoe, Illinois: The Free Press, 1963), pp. 206-18. Lieberson's figures are for 1930, following a prosperous decade of home buying that saw the percentage of black homeowners in $\mathrm{Ne}$ braska climb to 33.9 percent (Negroes in the United States [note 15 above], p. 260). I do not have home ownership data for the Prince Hall Masons for 1930, but their rates from 1920 already compare favorably with the immigrant data from 1930.

17. Muraskin, Middle-class Blacks (note 1 above), p. 41 ; notes $119,120,121$.

18. Negro Population, $1790-1915$ (note 8 above), p. 209.

19. The Mississippi photograph is included in the article "Fraternal Societies" in the Encyclopedia of Black America, ed. W. Augustus Low (New York: McGraw-Hill, 1981), p. 394, and the Nebraska photograph is in Joseph A. Walkes, Jr., Black Square and Compass: 200 Years of Prince Hall Freemasonry (Richmond, Virginia: Macoy Publishing and Masonic Supply Co., 1979), p. 73.

20. Green, "Fourteenth Numbering" (note 12 above), p. 136.

21. Deborah Lynn Kitchen, "Interracial Marriage in the United States, 1900-1980" (Ph.D. diss., University of Minnesota, 1993), p. 100.

22. Jacqueline Jones, Labor of Love, Labor of Sorrow: Women, Work, and the Family from Slavery to the Present (New York: Basic Books, 1985), p. 162.

23. Muraskin, Middle-class Blacks (note 1 above), p. 93; for an interpretation of Prince Hall Masonry that asserts its middle-class nature, see Williams, Black Freemasonry (note 1 above), pp. 92-93, 105.

24. Lynn Dumenil, Freemasonry and American Culture, 1880-1930 (Princeton: Princeton University Press, 1984), pp. 227, 229. 